\title{
Rethinking Colonial Poetry in an Atlantic Studies Context
}

\author{
(c) Kathleen Ross
}

New York University

E-mail-Kar1@nyu.edu

These remarks are based on a paper prepared for the 2000 Latin American Studies Association conference, for a panel entitled "Rethinking Latin American Studies: Poetry," organized by Roberto González Echevarría. I was the person on the panel speaking about the rethinking of colonial poetry within Latin American studies. Since then, I have pondered the matter a great deal from various angles. One important question I will focus on here is the context in which we generally examine and learn poetry within Colonial studies, that is, the way we organize material in the classroom and in our scholarly work, and the place of poetry within that structure. The reconfiguring of Colonial studies as a part of Atlantic studies offers a useful framework for thinking through change in the field and points to new and promising avenues for teaching and research, some of which are already emerging. But before discussing future possibilities, let me first backtrack to consider where we are in the present.

I begin by observing, as I did at the LASA 2000 meeting, that despite the explosion of Latin American Colonial studies over the last two decades, despite all the international activity surrounding the quincentenary of 1992, despite the extremely healthy, self-questioning and innovative character of the field in general, studies of poetry, in quantity if not quality, have lagged behind those dealing with narrative to a noticeable degree. I must consider myself part of the problem, for despite my own deep involvement with the development of the colonial field over the last twenty years, pages devoted to colonial poetry have not figured prominently in my own work. Indeed, while teaching a graduate seminar on colonial poetry and theater last year, every time I heard myself saying, "This is a wonderful poem and very little work has been done on it"--and I repeated that phrase many times in the course of fifteen weeks--a little nagging voice entered my thoughts, asking, "And what about you?" Thus my comments today should be taken as an examination of my own critical practice, as well as that of the field at large. Why have we not written as much on colonial poetry as we have on colonial narrative forms? What could move more of us to engage colonial poetry with passion and critical rigor? 
Let me say from the outset that in this paper I will concentrate on what is not there, more than on what is. In particular, I will leave Sor Juana-certainly the most important exception that springs to mind--out of these comments entirely. She truly stands alone as an object of extensive, rich, and ongoing study. I will divide my comments into two sections, the first speculating on reasons that might lie behind the lack of work on colonial poetry, and the second moving into possible trends for the future.

\section{Dreams and memories}

In Bill Clinton's January 2000 State of the Union address, crafted of course for the new millenium which at long last is now finally here, he made the following statement: "After 224 years, the American Revolution continues. We remain a new nation. As long as our dreams outweigh our memories, America will be forever young. That is our destiny. And this is our moment." A clearer statement than this connecting the obliteration of the past to the domination of the present would be difficult to come by. The North American paradise, the new territory upon which to inscribe dreams of power and prosperity, still operates as a seductive call in this electronic age, even if the frontiers are now virtual ones. Memory ages us, while dreams make us forever young.

While this repeats the well-worn United States credo of endless possibility, of having it all, right now, I think there is much here for Latin American Colonial studies to consider also. As Walter Mignolo has demonstrated so convincingly in The Darker Side of the Renaissance, the destruction of Amerindian memory in Spanish America took many forms, and while none of them succeeded entirely in their devastation, the damage done was violent, ravaging, and lasting. And very recently, José Rabasa's new study, Writing Violence on the Northern Frontier, further elaborates on the oxymoronic term "peaceful conquest." The dreams of Europe--the invention of America-displaced the memories of the peoples and cultures encountered in conquest and colonization. That basic truth is what we, as students of the colonial period, always confront in our work. This has been recognized for a while now; and I would point to Rolena Adorno's 1988 essay, still much-quoted today, on "Nuevas perspectivas en los estudios literarios coloniales hispanoamericanos," as a landmark that made quite clear the need to include the Amerindian presence in any analysis of colonial discourse, which is but a western monologue without it.

Dreams and memories, it would seem, form an essential part of colonial Spanish American discourse, which is the discourse of 
empire--especially of the Atlantic empire. I submit, then, that the place of poetry in that discourse is more difficult to define than that of narrative, and that in our effort to recast the field of Colonial studies along inclusive, interdisciplinary and anti-hegemonic lines, poetry and poetic language have often been left out. After all, critics and theorists have our dreams too; our field is young, and perhaps we would like it to stay that way. Perhaps poetry is the memory of a literary language we would rather forget and shed like an old skin.

Yet to study colonial culture without studying poetry is absurd. Whether we speak of Amerindian, criollo, Spanish or mestizo voices, what dominates, what is silenced, or what is in-between, poetry stands as a significant and essential element of colonial life. Poetry, as an oral as well as a written form, may in fact be the one expression common to all sectors of colonial society. Amerindian memory and African culture survived in poetry; baroque criollos found themselves in poetry; a whole colonial society of spectacle and excess relied on poetry, if we expand poetry to mean theater also, for collective celebration and public ritual.

Certainly Balbuena's La grandeza mexicana tells us as much about the first century of colonization in New Spain as do the chronicles of Cortés and Bernal Díaz, or the histories of Acosta or Las Casas, or the tracts of Sahagún. Nevertheless, the dearth of recent work on Balbuena, with only a few exceptions (such as that of Daniel Torres), attests to the difficulty of knowing what to say about the poem. Nor is this a case where access to the text can be claimed as an obstacle; there are very good modern editions of Balbuena. I find this instance of critical neglect especially intriguing, given that Balbuena's poem, as has been noted by critics as diverse as Angel Rama and Roberto González Echevarría, occupies such a foundational place in Spanish American literary history. This dream of the perfect criollo city, built on the ruins of Tenochtitlan's wrecked memories, waits for an extensive new study.

Perhaps, then, resistance to studying colonial poetry--and here I speak just of poetry written in Spanish--lies with its traditional roots in Spanish Golden Age poetics. We cannot speak of hybridity in poetry in the same way we do regarding the narrative; what is new, what is more than derivative, is much more elusive in poetry, even much baroque poetry, which is, of course, the one area where a great deal of attention has been successfully focused. Sometimes, in fact, the only thing obviously new is the location of the poet on American soil, and as we know by now, making too much of mere geography results in simplistic readings. To find something new in traditional poetry, one must master the tradition and work with it, and life is short. 
Nevertheless, I would argue, colonial discourse and colonial poetics are inseparable. Because colonial writers often wrote both poetry and prose, those of us studying the period would do well to follow suit by rethinking our critical object. Abandoning or ignoring the poetry written during the colonial period, and its relationship, or lack of relationship to the poetry sung or recited at the same time, impoverishes the work we do.

\section{Pleasure and lies}

In 1992, in celebration of its twentieth anniversary, Latin American Literary Review invited two dozen or so critics to reflect on the future of the field. Mercedes López-Baralt contributed an essay entitled "Is There Life after 1992? On the Future of Colonial Studies" which discussed why contemporary critics and writers can enjoy the pleasure of the text in historical documents of the colonial period, as opposed to poetry or other texts written for aesthetic reasons, where presumably the source of pleasure would usually be more obvious. According to her formulation,

The key to the pleasure of our reading of colonial literature is in discovering the distance between historical reality and the image of that same reality constructed by words. We are talking, then, of the contriving of lies, which is what fictionalization--or the distance between words and things, as Foucault would have it--is all about, and without which literature would not be possible. (63)

Although the field has since moved far away from the old dichotomizing mode of searching out fictional passages in colonial texts, toward a discursive model encompassing all kinds of textual and non-textual elements in our reading, I think the role of pleasure and lies in Colonial studies is worth reconsidering. For unless we assume that pleasure never enters the picture and we all just toil at this for material gain, what becomes clear is that all those non-aesthetic documents have been and continue to be a source of pleasure for many of us, even if we no longer need to call chronicles "novels" to make it so. Most of the supposedly aesthetic creations, on the other hand, again with the great exception of Sor Juana's corpus, leave us cold, so cold we just don't seem to care. In the past it would have been said that we find no truth in them. Could it be, however, that the problem for critics today is that the lies those poems tell just aren't big enough? That the distance between words and things shrinks in poetry, which is more about language itself to begin with? And that without a good lie, the pleasure doesn't follow? 
Some of the most successful recent examples of work on colonial poetry delve precisely into this fissure of historical reality and words. I am going to take up two examples here, drawn from very different periods and types of poetic composition. First will be the epic poetry of the late sixteenth century, as it emerges in recent studies by James Nicolopulos and others. Second will be the popular poetry of eighteenth-century New Spain confiscated by the Inquisition, as presented in a recent volume edited by María Agueda Méndez and Georges Baudot.

I first consider a set of two essays recently published by James Nicolopulos on Alonso de Ercilla's La Araucana. The arguments of these mutually complementary articles are further developed in the author's volume The Poetics of Empire in the Indies: Imitation and Prophecy in La Araucana and Os Lusíadas. Nicolopulos's reasoning is complex; I will paint it in broad strokes to show why in my view it constitutes such a promising example of new scholarship on colonial poetry, and in the interests of time collapse together the two pieces, one of which appeared in Latin American Literary Review (JulyDecember 1998), the other in Georgina Sabat de Rivers's excellently edited collection "Esta, de nuestra América pupila": Estudios de poesía colonial.

Briefly, in taking up the question of the reception of La Araucana by other poets writing in late sixteenth-century Peru and New Spain-principally Pedro de Oña, but also Diego Dávalos y Figueroa and Balbuena--Nicolopulos brings into play a plurality of contemporaneous literary, political and economic influences. Foremost among them figures the Petrarchan practice of those criollo poets, as filtered through their reading of metropolitan Spanish poetry from a position at the periphery of empire. Coupled with the literary debates of the era is the one between royalists and encomenderos concerning the future fate of Amerindian subjects. Nicolopulos skillfully shows how all these factors must be considered together to read in a new way Ercilla's inclusion of Amerindian characters in La Araucana, both male and female, and their later echoes in other poets' works. Through the centuries, the author tells us, the amorous passages of La Araucana in particular have inspired varied responses:

This enthusiastic reception in the Iberian Peninsula was not always echoed in the New World, where during the same decade of the 1590s these representations of indigenous lovers were to have a powerful, although much more negative and complex, impact on some colonial readers. It is my contention that these colonial responses can shed considerable light on some of the on-going critical questions about the nature and function of these amorous passages that have 
so delighted, bedeviled and perplexed readers of the Araucana over the years. ("Reading and Responding" 227)

Nicolopulos thus shifts the question away from the text's truth or lies as we perceive them today, onto the controversy among colonial poets themselves of just whose truth or lies would prevail, in both poetic and material terms.

José Antonio Mazzotti and Paul Firbas, working across the colonial period in various regions and centuries, have also published new and exciting work on epic poetry. It would seem that an Atlantic studies context and the epic are made for each other, or perhaps I should say, they made each other, since empire and epic are indeed tightly bound. Here we have one of the most fruitful areas of future study and one that may open the door to a renewed interest in lyric poetry as well.

A very different case of amorous texts is the focus of Méndez and Baudot's Amores Prohibidos: La palabra condenada en el México de los virreyes. Antología de coplas y versos censurados por la Inquisición de México (1997). By presenting censored poems of the eighteenth century accompanied by the texts of the Inquisition's accusatory documents, the editors provide an especially rich portrait of late colonial Mexican culture and the role within it of popular poetry. Moreover, they have made accessible a variety of compositions, first grouping together the various sones, bailes, coplas y cantos, then proceeding on to examples of love poetry written by clerics, erotic and satirical poems, and verses considered heretical in a more strictly religious sense.

Some of this poetry is quite simple, some much more sophisticated. But from the scandalously suggestive El Chuchumbé, sung and danced by mulattoes and sailors in Veracruz (28-41), to the one hundred satirical poems comprising the "Décimas a las prostitutas de México" (166-195), to the coplas a lo divino sung by a friar in the company of a woman "que tenía instruida . . . de que el modo de vencer las tentaciones de la carne era ponerse en la ocasión próxima con él" (110), these poems demonstrate that our knowledge of colonial culture, particularly as it pertains to race and gender, remains far from complete. The limits of confining our reading to the wellordered lettered city could not be clearer than in these pages. They deserve our close attention and study.

The leap from exquisite Italianate octaves representing the most powerful of royalist tendencies, to simple poems that resist the repressive apparatus of Church and state may seem large.

Nonetheless, these are two instances in which recent work on colonial 
Spanish American poetry takes pleasure in texts that throw into question the truth and lies of what we read, and in turn gives us the pleasure of a new critical perspective. More could follow their example, as we rethink a field of dreams that cannot live without memories.

I wish to conclude with a consideration of how rethinking colonial poetry in the Atlantic studies context might play out in the classroom. I have always found it convenient to separate prose and poetry in my graduate seminars, as that particular system allows a great deal of freedom to study different critical approaches and types of text, but much gets lost with this generic division and it may have outlived its usefulness. As an example, satire, a mode so rich from so early on in poetry and theater, doesn't show up in prose until much later. This of course has everything to do with the ways in which the Atlantic empire was managed, documented, and controlled. Unless prose and poetry are studied side by side, the question of how satire developed from within different colonial sectors, and where resistance was located, does not get fully illustrated.

Studying colonial culture does require specific historical and geographical placement of discourse, and we are learning more and more just how important it is to differentiate along temporal lines as well. Focusing on the development of the Atlantic empire as a way of organizing our material incorporates those specificities, while making possible new points of contact and comparison. Clearly, we do not want to repeat the old ways of looking at Spanish and Portuguese empire, which I would call a "golden age" approach, nor do we want to surf the waves of postcolonial theory without first locating the ocean in which we swim. But as we make our own scholarly exploration, poetry should always make the voyage too, accompanying us as it did those whom we study.

\section{Works Cited}

Adorno, Rolena. "Nuevas perspectivas en los estudios literarios coloniales." Revista de crítica literaria latinoamericana 28 (1988): 11 27.

Clinton, William Jefferson. "The State of the Union: A New Century, A New Economy." The New York Times, Friday, January 28, 2000: A17.

Firbas, Paul. "Escribir en los confines: épica colonial y mundo antártico." In Mazzotti, ed., Agencias criollas, 191-213. 
González Echevarría, Roberto. "Colonial Lyric." In The Cambridge History of Latin American Literature, Vol. I.

Roberto González Echevarría and Enrique Pupo-Walker, eds. Cambridge: Cambridge UP, 1996. 191-230.

López Baralt, Mercedes. "Is There Life after 1992? On the Future of Colonial Studies." Latin American Literary Review 40 (1992): 63-65.

Mazzotti, José Antonio, ed. Agencias criollas: La ambigüedad "colonial" en las letras hispanoamericanas. Pittsburgh, PA: Biblioteca de América, 2000.

---. "Resentimiento criollo y nación étnica: el papel de la épica novohispana." In Agencias criollas, 143-160.

Méndez, María Agueda and Georges Baudot. Amores Prohibidos: La palabra condenada en el México de los virreyes. Antología de coplas y versos censurados por la Inquisición de México. México: Siglo Veintiuno Editores, 1997.

Mignolo, Walter. The Darker Side of the Renaissance: Literacy, Territoriality, and Colonization. Ann Arbor: The University of Michigan Press, 1995.

Nicolopulos, James. "Reading and Responding to the Amorous Episodes of the Araucana in Colonial Peru." In Sabat de Rivers, ed. 227-247.

---. "Pedro de Oña and Bernardo de Balbuena Read Ercilla's Fitón." Latin American Literary Review 52 (1998): 100-119.

---. The Poetics of Empire in the Indies: Imitation and Prophecy in La Araucana and Os Lusíadas. University Park, PA: The Pennsylvania State University Press, 2000.

Rabasa, José. Writing Violence on the Northern Frontier. Durham: Duke University Press, 2000.

Rama, Angel. "Fundación del manierismo hispanoamericano por Bernardo de Balbuena." University of Dayton Review 16:2 (1983), 1322. 
Sabat de Rivers, Georgina, ed. Esta de nuestra América pupila: Estudios de poesía colonial. Houston: Society for Renaissance \& Baroque Hispanic Poetry, 1999.

Torres, Daniel. "De la utopía poética en Grandeza mexicana de Bernardo de Balbuena." In Sabat de Rivers, ed. 86-93. 